\title{
Green synthesized hydroxamic acid administered in high dose disrupts the antioxidant balance in the hepatic and splenic tissues of albino rats
}

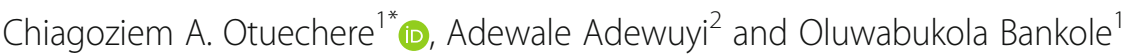

\begin{abstract}
Background: Hydroxamic acids are currently being used in diverse biological activities. We investigated the effect of hydroxamic acid, synthesized from Cyperus esculentus seeds, on the antioxidant status of the liver, spleen, and kidney of Wistar rats.

Methods: Twenty male rats were randomly divided into three treatment groups using hydroxamic acid at doses of 5,15 , and $50 \mathrm{mg} / \mathrm{kg}$ and a control group using distilled water. Rats were sacrificed $24 \mathrm{~h}$ after a seven-day repeated oral dosing. After that, the activities of superoxide dismutase (SOD), catalase (CAT), glutathione peroxidase (GPx), glutathione-S-transferase (GST), and the levels of glutathione (GSH) and malondialdehyde (MDA) were investigated in the organs.

Results: Our data showed that MDA levels remained unaltered in the liver, spleen, and kidney. However, it was found that hydroxamic acid at the dose of $50 \mathrm{mg} / \mathrm{kg}$ significantly increased SOD activity but depleted CAT, GPX activities and GSH levels in the liver when compared to the control groups. In splenic tissue, SOD activity and GSH levels were significantly diminished. Contrarily, in the kidney, treatment of rats with $50 \mathrm{mg} / \mathrm{kg}$ hydroxamic acid did not affect SOD activity, but GPx activity was increased while GST activity was decreased when compared to the controls.

Conclusion: Overall, hydroxamic acid may enhance antioxidant enzyme activities in the liver and kidney. However, caution is required at higher doses to forestall oxidative stress in the hepatic and splenic tissues.
\end{abstract}

Keywords: Antioxidant status, Cyperus esculentus, Hydroxamic acid, Liver, Spleen

\section{Introduction}

The biosynthesis of hydroxamic acid compounds presents high potentials due to their versatile applications and biological activities. Hydroxamic acids are groups of naturally occurring and synthetic weak organic acids with general formula $\mathrm{R}-\mathrm{CO}-\mathrm{N}-\mathrm{OH}$. They are common in the tissues of plants and metabolites of bacteria and fungi. Hydroxamic acids are generally synthesized by the chemical reaction of an alkyl or aryl ester with hydroxylamine in high alkaline medium. Fatty hydroxamic acids

\footnotetext{
* Correspondence: goziemo12@yahoo.com

${ }^{1}$ Department of Biochemistry, Faculty of Basic Medical Sciences, Redeemer's

University, Ede, Osun State, Nigeria

Full list of author information is available at the end of the article
}

have been synthesized via refluxing of triacylglycerides, palm olein, palm stearin, or corn oil with hydroxylamine hydrochloride [1]. Fatty hydroxamic acid derivatives have also been synthesized from palm kernel oil in a biphasic hexane/aqueous medium using Lipozyme TL IM as a catalyst [2]. Metalloenzymes such as carbonic anhydrase, leukotriene A4 hydrolase, matrix mettalloprotease, urease, and histone deacetylase have been implicated in the etiology of cancer due to their roles in stimulating cell division. Consequently, the metal-scavenging effect of hydroxamic acids, which could block the activities of these enzymes, has been exploited as a pharmacotherapeutic strategy against cancer and other allied ailments [3]. Specifically, hydroxamic acid compounds have found 
applications as histone deacetylase inhibitors [4], inhibitors of metallo-ß-lactamase [5], antitumor [6], antitrypanocidal [7] and antibacterial agents [8]. Their antiradical, chelating, and antioxidant properties have also been reported [9]. Suberoyl bis-hydroxamic acid has been reported to exert anti-growth effects in several malignancies, including breast cancer [10]. Furthermore, the hydroxamic acids could be incorporated into polymers for use as ion-exchange resins or for water treatment [11].

There are several ways of synthesizing hydroxamic acid compounds. The most important route is via the $\mathrm{N}$ alkylation of O-substituted hydroxylamine using various alkylating agents. However, this synthetic strategy is expensive and potentially toxic as by-products are released in the process [3]. As an alternative, research on the possible bio-applications of green synthesized compounds is gaining currency. Silver nanoparticles prepared from Salvia officinalis extract have been reported to possess antioxidant and anti-inflammatory activities [12]. Similarly, azomethine synthesized from cinnamaldehyde, obtained from the bark of a cinnamon tree, has been shown to have antidepressant activity [13]. In this study, we have synthesized hydroxamic acid from the seeds of Cyperus esculentus (common name Tiger nut). Mineral and vitamin analyses of the seeds of Cyperus esculentus revealed the presence of essential elements (phosphorus, magnesium, potassium, calcium, etc) and water-soluble vitamin C [14]. Volatile constituents of Cyperus esculentus such as p-Vinylguaiacol and cyprotundone, with antioxidant activities have also been identified [15]. Recently, Nwozo and Nwawuba [16] reported the antioxidant enzymes enhancement potential of $C$. esculentus oil in a rat model of experimental Type 2 diabetes.. The objective of this study is the green synthesis of hydroxamic acid and the evaluation of its effects on antioxidant homeostasis in key organs (liver, kidney, and spleen) of rats prior to its utilization as a useful pharmaceutical compound.

\section{Methods}

\section{Green synthesis of hydroxamic acid}

The seeds of Cyperus esculentus were purchased from Festac Town market in Lagos State, Nigeria and identified at the Herbarium Unit, Botany Department University of Ibadan. Hydroxamic acid was synthesized from $C$. esculentus seeds, as previously described [17]. Briefly, oil extracted from the seeds of $C$. esculentus was reacted with $2.75 \mathrm{~g}$ of hydroxylamine hydrochloride and $16.5 \mathrm{~mL}$ of water, followed by addition of potassium hydroxide, and ethanol. The mixture was gently warmed for $10 \mathrm{~min}$. After cooling, the resulting solid was filtered and dried to give hydroxamic acid. The infrared spectra of hydroxamic acid have been previously reported [17].

\section{Animals}

Experiments were performed on healthy, male Wistar rats weighing approximately $270-320 \mathrm{~g}$. Animals were obtained from the primate colony of the Department of Veterinary Pathology, University of Ibadan, Nigeria. All animals received humane care by guidelines governing the handling of laboratory animals as outlined by the Redeemer's University Committee on Ethics for Scientific Research. Before dosing, they were acclimatized for 14 days and subjected to natural photoperiod of $12 \mathrm{~h}$ light/ $12 \mathrm{~h}$ dark cycle. The animals were housed in stainless cages with the temperature maintained at $25 \pm 2{ }^{\circ} \mathrm{C}$. Rats were fed on a commercial pelleted diet (Ladokun Feeds Ibadan, Nigeria) and drinking water ad libitum.

\section{Experimental design}

Twenty rats were randomized into four groups of five animals each and were treated as follows for seven days:

- Control: administered $1 \mathrm{ml}$ distilled water, orally, once, daily

- Treatment groups 1-3: administered 5, 15, and 50 $\mathrm{mg} / \mathrm{kg}$ hydroxamic acid, respectively, orally, once, daily. These doses represented low, medium, and high doses of exposure, as reported previously [17].

\section{Tissue processing}

At the termination of studies, rats were sacrificed by cervical dislocation. Liver, kidney, and spleen tissues were harvested, rinsed in ice-cold potassium chloride solution and homogenized in phosphate buffer $(0.1 \mathrm{M}, \mathrm{pH}$ 7.4). Homogenates were centrifuged at $12000 \mathrm{~g}$, and the supernatants were used for biochemical assays.

\section{Estimation of superoxide dismutase (SOD) activity}

The SOD activity was determined using the method of Misra and Fridovich [18]. Briefly, $3 \mathrm{~mL}$ of freshly prepared epinephrine was added to a reaction mixture containing $2.5 \mathrm{~mL}$ of sodium carbonate buffer and $0.02 \mathrm{~mL}$ of homogenate (Liver, spleen, and kidney). Change in absorbance was monitored at $480 \mathrm{~nm}$ at intervals of $60 \mathrm{~s}$ for $180 \mathrm{~s}$.

\section{Estimation of catalase (CAT) activity}

CAT activity in liver, kidney, and spleen homogenates was determined by the procedure of Sinha [19]. Briefly, homogenates $(0.1 \mathrm{~mL})$ were incubated with $0.5 \mathrm{ml}$ of $\mathrm{H}_{2} \mathrm{O}_{2}$ in the presence of $0.01 \mathrm{M}$ phosphate buffer $(\mathrm{pH}$ 7.4). The reaction was terminated by adding $5 \%$ dichromate solution. The reaction mixture was incubated at $100{ }^{\circ} \mathrm{C}$ for $15 \mathrm{~min}$. The CAT activity was measured in terms of the amount of $\mathrm{H}_{2} \mathrm{O}_{2}$ consumed. 
Estimation of glutathione peroxidase (GPx) activity The activity of GPx was evaluated by the method of Rotruck et al. [20]. Briefly, an assay mixture containing $0.5 \mathrm{~mL}$ sodium phosphate buffer, $0.1 \mathrm{~mL}$ sodium azide, $0.2 \mathrm{~mL}$ glutathione, $0.1 \mathrm{~mL} \mathrm{H}_{2} \mathrm{O}_{2}$ and $0.2 \mathrm{~mL}$ of homogenates (liver, kidney, and spleen) was incubated for $3 \mathrm{~min}$ at $37^{\circ} \mathrm{C}$, before termination of reaction with $0.5 \mathrm{~mL}$ of trichloroacetic acid (TCA). After centrifugation, $4 \mathrm{~mL}$ disodium hydrogen phosphate and $1 \mathrm{~mL}$ of $5,5^{\prime}$-Dithiobis (2-nitrobenzoic) acid (DTNB) were added to the supernatant and absorbance was measured at $412 \mathrm{~nm}$.

\section{Estimation of glutathione S-transferase (GST) activity}

GST activity was determined, according to Habig et al. [21]. In this procedure, assay mixture containing 0.03 $\mathrm{mL}$ of homogenates (liver, kidney, and spleen), $2.79 \mathrm{~mL}$ phosphate buffer, $0.15 \mathrm{~mL}$ of 1-chloro-2, 4,-dinitrobenzene and $0.03 \mathrm{~mL}$ of GSH were mixed by inversion and immediately read at $340 \mathrm{~nm}$ against sample blank 60-s interval for $180 \mathrm{~s}$.

\section{Estimation of glutathione (GSH) level}

For the quantification of GSH, absorbance recorded at $412 \mathrm{~nm}$, as previously described by Beutler et al. [22]. Briefly, a reaction mixture containing $0.2 \mathrm{~mL}$ of homogenates (liver, kidney, and spleen), $3.3 \mathrm{~mL}$ of sulfosalicylic acid and $1.5 \mathrm{~mL}$ distilled water allowed to stand for 5 min and filtered to obtain a supernatant. Subsequently, $0.5 \mathrm{~mL}$ DTNB in phosphate buffer, was added to the reaction mixture, and measured spectrophotometrically after $15 \mathrm{~min}$.

\section{Estimation of malondialdehyde (MDA) level}

The MDA level was estimated according to a previous protocol [23]. 0.4 $\mathrm{mL}$ of homogenates (liver, kidney, and spleen) was mixed with $1.6 \mathrm{~mL}$ of Tris- $\mathrm{KCl}$ buffer to which $0.5 \mathrm{~mL}$ of TCA and TBA were added. The reaction mixture was incubated in a water bath for $45 \mathrm{~min}$ at $80^{\circ} \mathrm{C}$, then cooled and subjected to centrifugation at 3000 g. Absorbance was measured at $532 \mathrm{~nm}$. A molar extinction coefficient of $1.56 \times 10^{-5} \mathrm{M}^{-1} \mathrm{~cm}^{-1}$ was utilized in computing the MDA levels.

\section{Estimation of Total protein}

The protein concentrations in homogenates (liver, kidney, and spleen) were assayed according to the method of Gornall et al. [24].

\section{Statistical analysis}

Data are expressed as the mean \pm standard error of the mean (SEM). Statistical significance was determined by one-way analysis of variance (ANOVA) and complemented with Duncan's multiple comparisons between control and treated animals in all groups using Graph Pad
Prism statistical software. P-values less than 0.05 were considered to indicate statistical significance.

\section{Results \\ Effect of hydroxamic acid on defensive antioxidant enzymes}

The activity of SOD in liver, kidney, and spleen of rats treated with 5,15 , and $50 \mathrm{mg} / \mathrm{kg}$ hydroxamic acid, respectively, is shown in Fig. 1. The low and medium doses ( 5 and $15 \mathrm{mg} / \mathrm{kg}$ ) of hydroxamic acid did not affect SOD activity in the liver and kidney. However, the 50 $\mathrm{mg} / \mathrm{kg}$ hydroxamic acid significantly $(p<0.01)$ elevated the SOD activity in the liver by $83.5 \%$ compared to the control group. Contrariwise, there was a significant decrease in SOD activity in the spleen of rats. Figure 2 showed that the treatment of rats at all doses of hydroxamic acid did not elicit any significant change in the kidney and spleen CAT activities, whereas treatment with 15 and $50 \mathrm{mg} / \mathrm{kg}$ hydroxamic acid caused significant $(p<0.05)$ and dose-dependent decrease in CAT activity in the liver compared to their respective controls.

\section{Effect of hydroxamic acid on glutathione antioxidant defenses}

Figure 3 indicates the changes in GPx activities in liver, kidney, and spleen of rats exposed to hydroxamic acid at the doses of 5,15 , and $50 \mathrm{mg} / \mathrm{kg}$. At the $50 \mathrm{mg} / \mathrm{kg}$ treatment dose, there was a significant $(p<0.01)$ increase in GPx activity in the kidney. Furthermore, hydroxamic acid, at all doses, significantly $(p<0.01)$ inhibited GPx activity in the liver. However, administration of hydroxamic acid at all treatment doses did not significantly alter the GPx activities in the spleen. Figures 4 and 5 summarize the GST activities and GSH levels in rats exposed to hydroxamic acid. The changes in GST and GSH revealed different effects of hydroxamic acid in the specific organs. While the GST activities remained unchanged in the spleen, intoxication of rats with hydroxamic acid at the $50 \mathrm{mg} / \mathrm{kg}$ dose elicited a significant $(p<0.05)$ depletion of GST activity in the kidney compared with the control group. Contrariwise, administration of hydroxamic acid at the 5 and $15 \mathrm{mg} / \mathrm{kg}$ doses elicited a significant $(p<0.01)$ induction in GST activity in the liver. At the $5 \mathrm{mg} / \mathrm{kg}$ hydroxamic acid dose, there was a non-significant increase in GSH levels in the liver and spleen. However, the splenic GSH levels were significantly diminished $(p<0.05)$ following treatment of rats with $50 \mathrm{mg} / \mathrm{kg}$ hydroxamic acid (Fig. 5).

\section{Effect of hydroxamic acid on malondialdehyde levels}

There was no treatment-related changes in the liver, kidney, and spleen MDA levels following the administration of hydroxamic acid at the 5, 15, and $50 \mathrm{mg} / \mathrm{kg}$ doses (Fig. 6). 

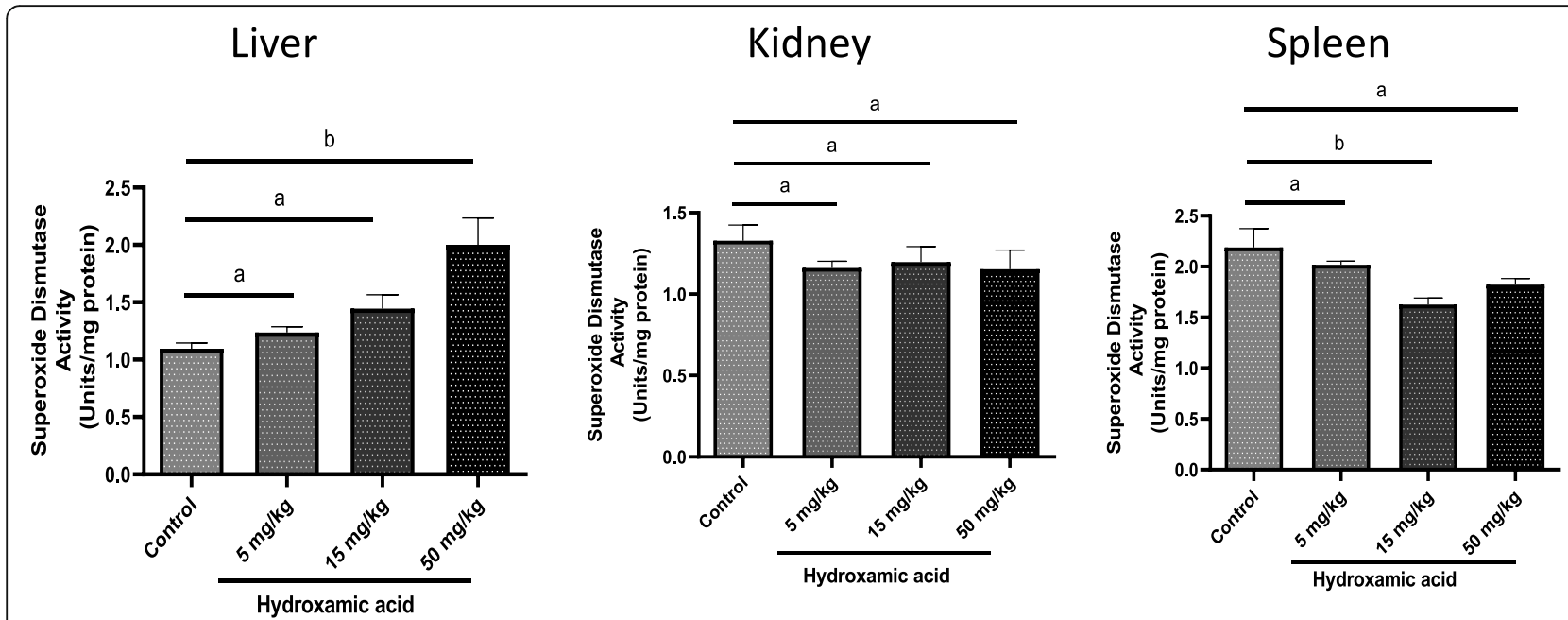

Fig. 1 Superoxide dismutase activity in liver, kidney, and spleen. Values are expressed as mean \pm SEM; $(n=5)$. Different letters indicate significant difference at $p<0.05$

\section{Discussion}

The present study evaluated the effect of hydroxamic acid on antioxidant homeostasis in the liver, kidney, and spleen of rats after short-term treatment. The results revealed that hydroxamic acid caused an imbalance in hepatic and splenic antioxidant markers, especially at the high dose treatment of $50 \mathrm{mg} / \mathrm{kg}$.

Antioxidant defenses, ubiquitous in aerobic organisms, comprise of antioxidant molecules that serve an innate protective role by scavenging free radicals [25]. These antioxidant defense molecules, including GSH, GST, CAT, SOD, GPx, glutathione reductase (GR) and glucose-6-phosphate dehydrogenase, can serve as indicators of oxidative stress in an organism [26, 27].

In the primary antioxidant defense mechanism, SOD catalyzes the dismutation of superoxide ion to hydrogen peroxide, which is then eliminated by CAT [28]. The present investigation showed that short-term administration of hydroxamic acid elicited alterations in the hepatic and splenic SOD activities as well as hepatic CAT activity. The increase in the hepatic activity of SOD indicates its induction by hydroxamic acid. An increase in SOD activity has been reported to be beneficial in the event of increased free radical generation [28]. On the other

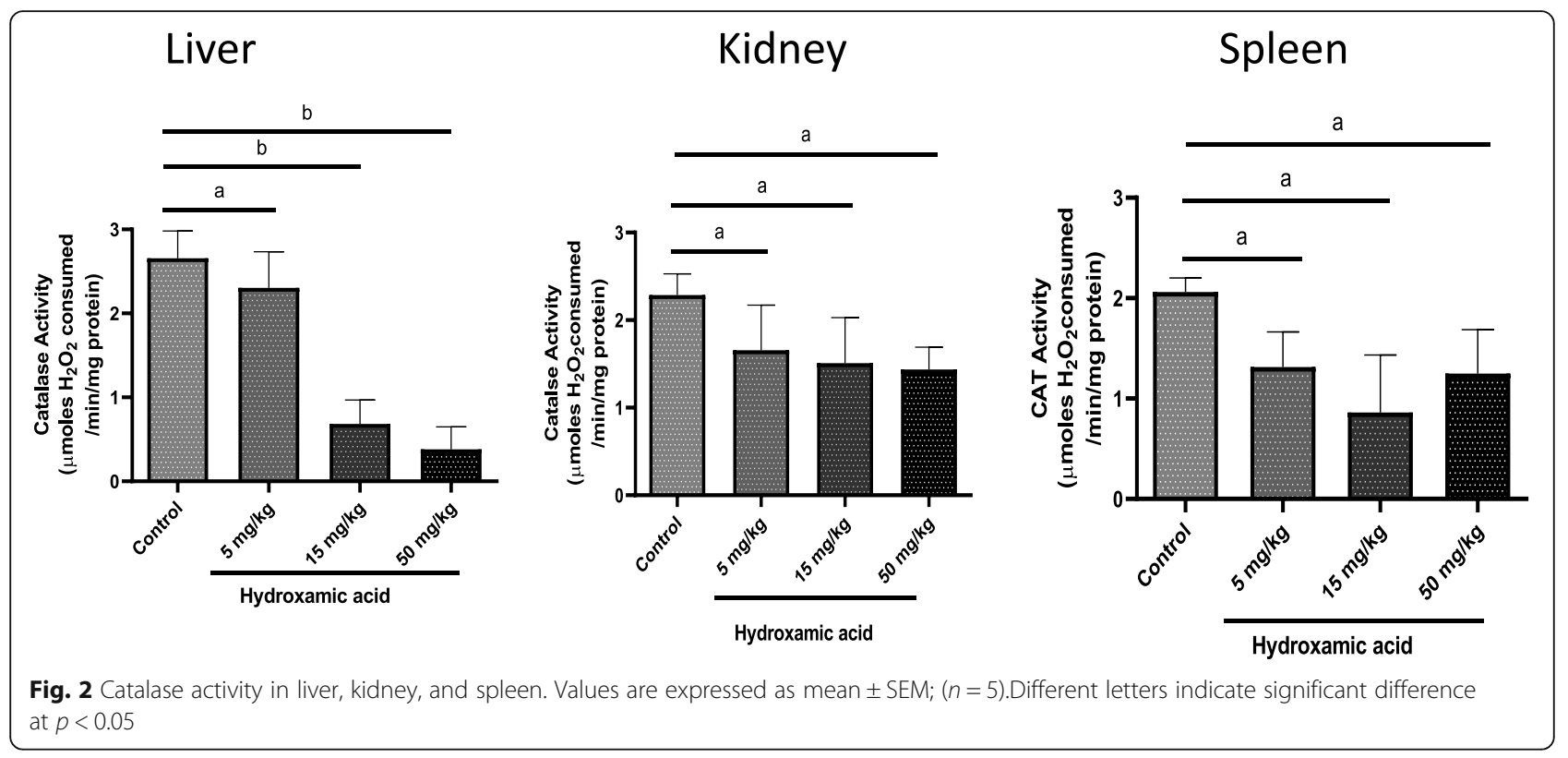



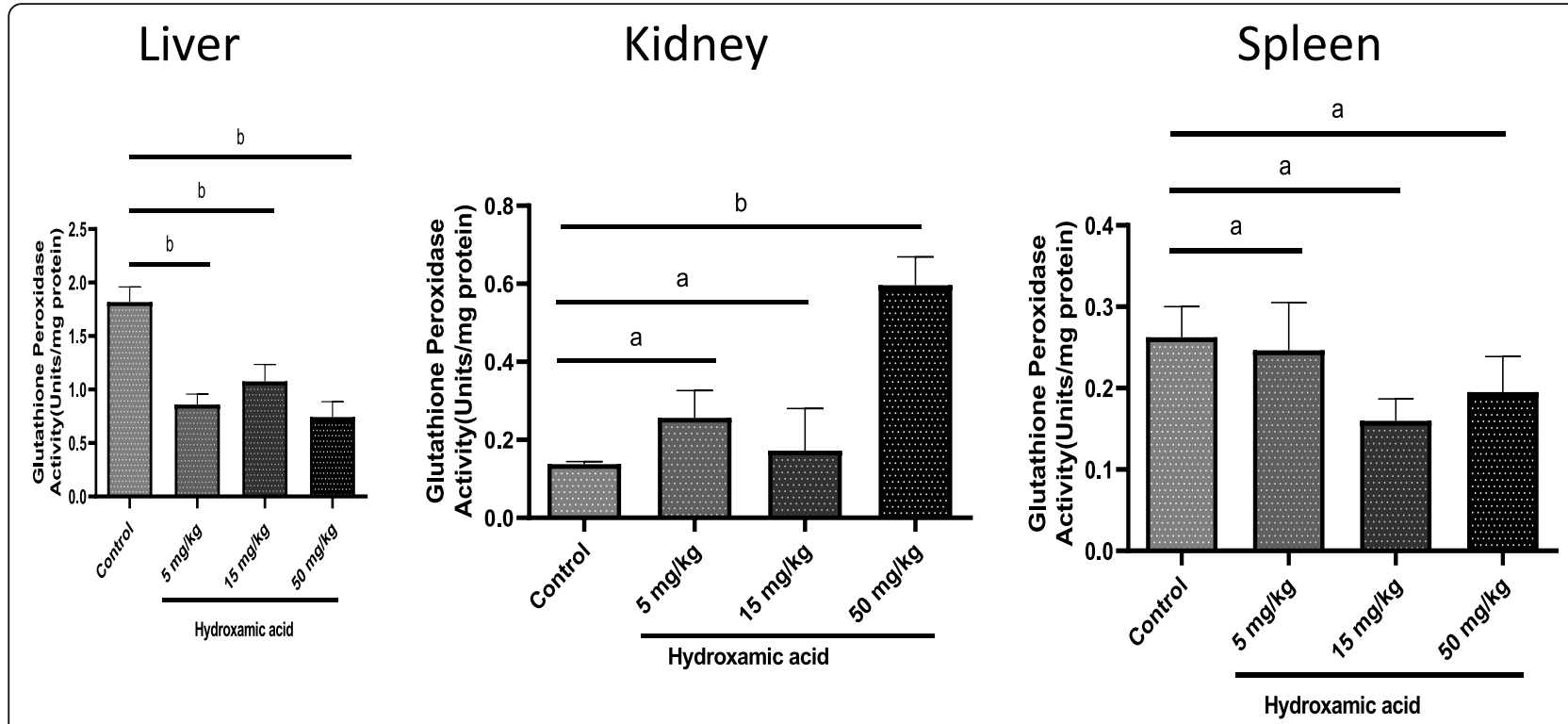

Fig. 3 Glutathione peroxidase activity in liver, kidney, and spleen. Values are expressed as mean $\pm \mathrm{SEM}$; $(n=5)$.Different letters indicate significant difference at $p<0.05$

hand, the decrease of CAT activity in response to higher doses of hydroxamic acid can reduce the protection against free radicals. A similar trend of a concomitant increase in SOD and decrease in CAT activities has also been observed in the testes of rats treated with cyclophosphamide [29]. It is also plausible that the depletion of splenic SOD activity following exposure to hydroxamic acid could affect its immune function, as suggested by Estruel-Amades and co-workers [30].

The glutathione redox cycle, which includes GSH, GPx, and GR, plays a vital role in the detoxification of ROS, to protect cells from the potential toxicity and carcinogenesis
[31]. On the other hand, GST is a family of isoenzymes that catalyze the conjugation of GSH with a wide variety of organic peroxides (including lipid peroxides) to form more water-soluble products that are readily excreted from the system [32]. The highest dose of a hydroxamic acid $(50 \mathrm{mg} / \mathrm{kg})$ caused a significant decrease in GST activities in the kidney. The reduced activity of GST in this organ may partly be due to the lack of its substrate, GSH, and also because of oxidative modification of its protein structure. However, liver GST activity increased significantly at the doses of 5 and $15 \mathrm{mg} / \mathrm{kg}$. The organs' differences in enzyme activities might result from different

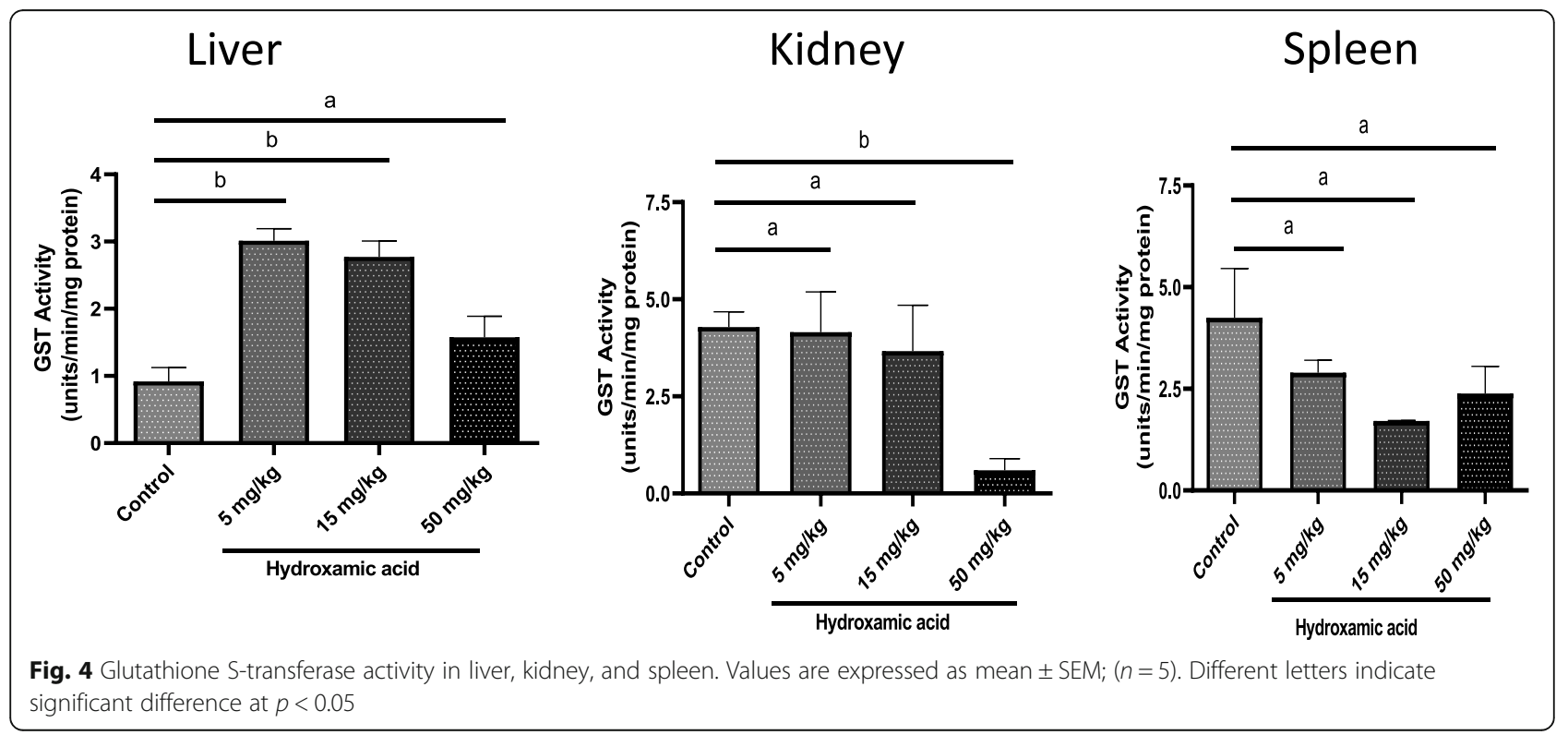



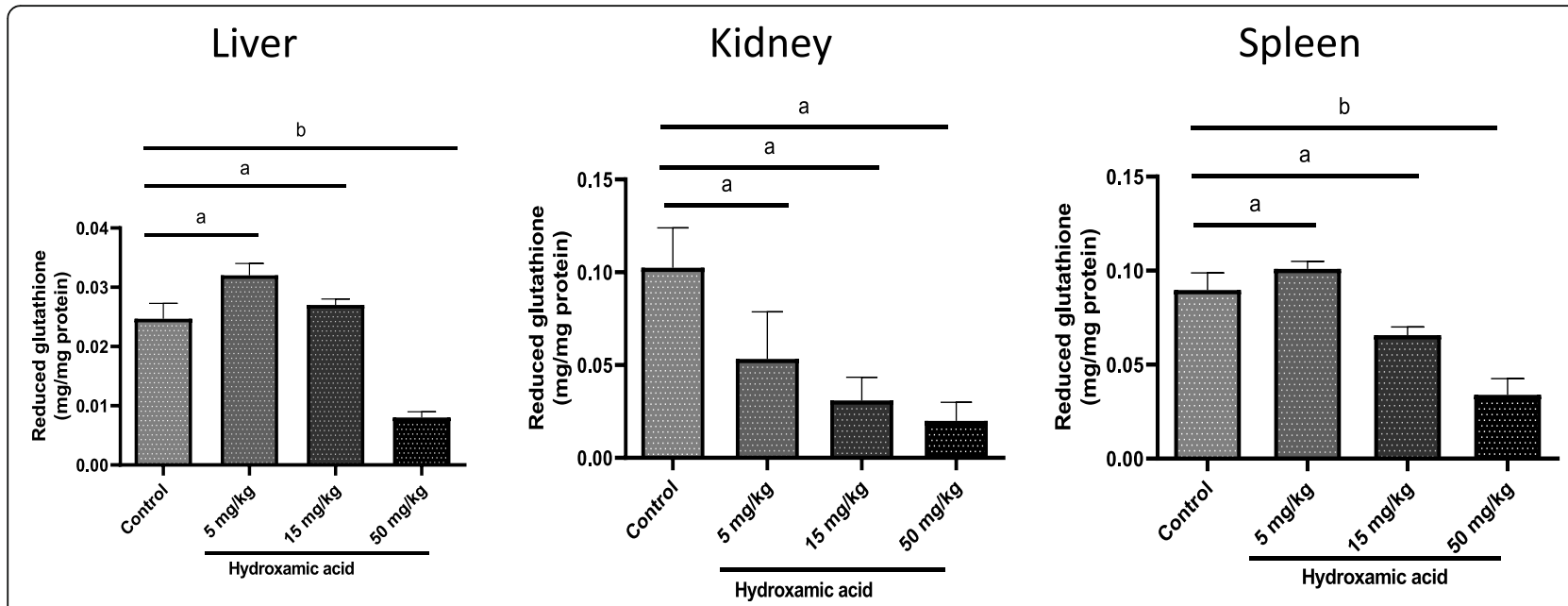

Fig. 5 Reduced glutathione level in liver, kidney, and spleen. Values are expressed as mean $\pm \operatorname{SEM} ;(n=5)$.Different letters indicate significant difference at $p<0.05$

metabolic rates and protein turnover. Another study [33] has reported a significant increase in GST activity in the liver, testes, and spermatozoa of rats treated with Garcinia kola. The inter-organ differences in response to antioxidant principles were further observed with a significant decrease in liver GPx across all treatment doses as against the significant increase observed in renal GPx activity in rats exposed to $50 \mathrm{mg} / \mathrm{kg}$ hydroxamic acid. This observed increase in renal GPx activity agreed with a previous study reporting an elevated GPx activity in the kidney of rats treated with nanocellulose synthesized from Khaya senegalensis seeds [34].

Furthermore, GSH depletion was prominent in the liver and spleen. In a similar study, Celik and co-workers
[35] reported that two plant growth regulators, abscisic and gibberellic acids, elicited alterations on the antioxidant defense systems in various tissues of the rats. By their studies, they reported that abscisic acid significantly depleted GSH levels in the spleen after a 50-day continuous oral dosing in rats. It has been suggested that the depletion of GSH in tissues may be as a result of its increased utilization by antioxidant enzymes such as GST [35]. In this study, administration of hydroxamic acid did not significantly alter the MDA levels in the organs. Our results were in disagreement with another study which reported that linoleyl hydroxamic acid decreased lipid peroxidation levels in blood, heart, liver, and lungs in rats under acute hypoxic hypoxia [36].

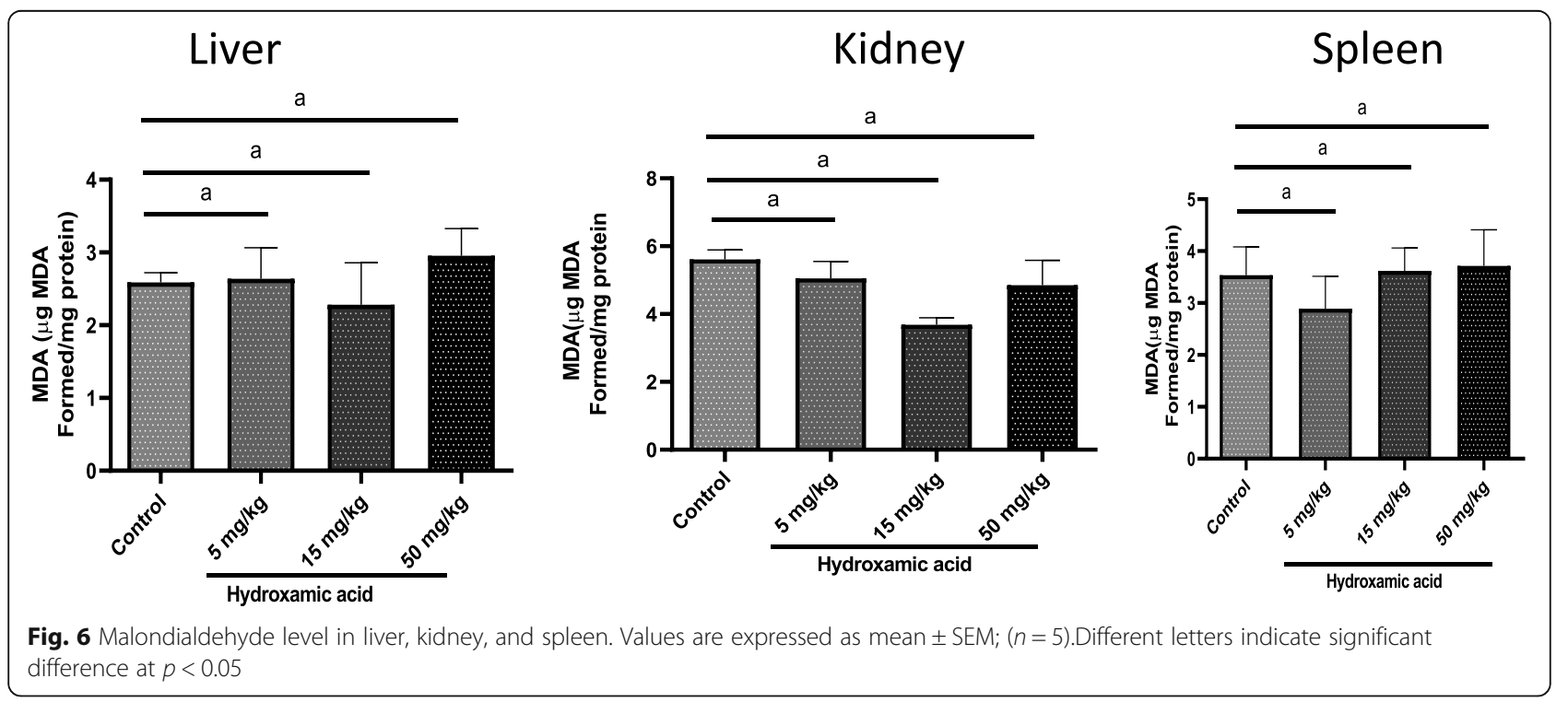




\section{Conclusion}

Hydroxamic acid synthesized from Cyperus esculentus seeds did not perturb the antioxidant balance at the lower doses of treatment; however, at the highest dose, the hepatic and splenic tissues may be vulnerable to oxidative stress. Overall, our study provided useful toxicological data to support the safe bio-applications of hydroxamic acid. Subsequent research emphasizing molecular mechanisms and morphological studies will further enhance understanding of the effects of hydroxamic acid exposure on vital organs.

\section{Abbreviations}

ANOVA: One-Way Analysis of Variance; CAT: Catalase; GPx: Glutathione Peroxidase; GR: Glutathione Reductase; GSH: Reduced Glutathione; GST: Glutathione S-Transferase; SOD: Superoxide Dismutase; TCA: Trichloroacetic acid; TP: Total proteins

\section{Acknowledgments}

The authors are grateful to the Department of Chemical Sciences, Redeemer's University, Ede, Osun State, Nigeria.

\section{Authors' contributions}

This work was carried out in collaboration between all authors. Authors CAO and AA designed the study; Author OB carried out the laboratory work. Authors CAO and AA supervised the work and participated in manuscript preparation. Authors approved the manuscript submission.

\section{Funding}

None.

\section{Availability of data and materials}

The dataset supporting the conclusions of this article is included as Figures uploaded as additional files.

\section{Ethics approval and consent to participate}

The principles governing the use of laboratory animals as laid out by the Redeemer's University, Ede Committee on Ethics for Scientific Research. The approved study code was RUN09-10/2435.

\section{Consent for publication}

Not applicable.

\section{Competing interests}

The authors declare that they have no competing interests.

\section{Author details}

'Department of Biochemistry, Faculty of Basic Medical Sciences, Redeemer's University, Ede, Osun State, Nigeria. ${ }^{2}$ Department of Chemical Sciences, Redeemer's University, Ede, Osun State, Nigeria.

Received: 26 June 2019 Accepted: 11 February 2020

Published online: 14 February 2020

\section{References}

1. Hoidy WH, Ahmad MB, Al-Mulla EA, Yunus WMZ, Ibrahim NA. Synthesis and characterization of fatty hydroxamic acids from triacylglycerides. J Oleo Sci. 2010;59:15-9.

2. Jahangirian H, Haron MJ, Yusof NA, Silong S, Kassim A, Rafiee-Moghaddam R, Peyda M, Gharayebi Y. Enzymatic synthesis of fatty hydroxamic acid derivatives based on palm kernel oil. Mol. 2011;16:6634-44.

3. Kant BR, Kant BS, Chand BT, Kumar BA. Green Synthesis of Hydroxamic Acid and Its Potential Industrial Applications. In: Kalia V, editor. Microbial Applications Vol.2: Springer: Cham; 2017. p. 169-84.

4. Mutule I, Borovika D, Rozenberga E, Romanchikova N, Zalubovskis R, Shestakova I, Trapencieris P. 5-membered cyclic hydroxamic acids as HDAC inhibitors. J Enzyme Inhib Med Chem. 2015;30:216-23.
5. Kim SK, Demuth M, Schlesinger SR, Kim SJ, Urbanczyk J, Shaw RW, Shin H. Inhibition of Bacillus anthracis metallo- $\beta$-lactamase by compounds with hydroxamic acid functionality. J Enzyme Inhib Med Chem. 2016;31(suppl 4): 132-7.

6. Klimanova EN, Vistorop IV, Sashenkova TE, Mishchenko DV, Neganova ME. DL-valine cyclic hydroxamic acid: Synthesis and potential chemosensitizing antitumor action. AIP Conference Proceedings. 2019; doi.org/https://doi.org/ 10.1063/1.5087357.

7. Menezes D, Calvet CM, Rodrigues GR, De Souza Pereira MC, Almeida IR, De Aguiar AP, Supuran $C T$, Vermelho AB. Hydroxamic acid derivatives: a promising scaffold for rational compound optimization in Chagas disease. J Enzyme Inhib Med Chem. 2015;31(6):964-73.

8. Sharma N, Kumari M, Kumar V, Chaudhry SC, Kanwar SS. Synthesis, characterization, and antibacterial activity of vanadium (IV) complexes of hydroxamic acids. J Coord Chem. 2010;63:176-84

9. Končić MZ, Barbarić M, Perković I, Zorc B. Antiradical, chelating and antioxidant activities of Hydroxamic acids and Hydroxyureas. Mol. 2011;16: 6232-42.

10. Yang $X$, Shi Z, Zhang N, Zhouluo O, Shen F, Xichun H, Zhenzhou S. Suberoyl bis-hydroxamic acid enhances cytotoxicity induced by proteasome inhibitors in breast cancer cells. Cancer Cell Int. 2014;14:107-14.

11. Johann T, Keth J, Bros M, Frey H. A general concept for the introduction of hydroxamic acids into polymers. Chem Sci. 2019;10:7009-22.

12. Baharara J, Ramezani T, Mousavi M, Asadi-Samani M. Antioxidant and antiinflammatory activity of green synthesized silver nanoparticles using Salvia officinalis extract. Ann Trop Med Public Health. 2017;10:1265-70.

13. Chigurupati S, Shaikh SA, Mohammad JI, Selvarajan KK, Nemala AR, Khaw $\mathrm{CH}$, Teoh CF, Kee TH. In vitro antioxidant and in vivo antidepressant activity of green synthesized azomethine derivatives of cinnamaldehyde. Indian J Pharmacol. 2017:49:229-35.

14. Suleiman MS, Olajide JE, Omale JA, Abbah OC, Ejembi DO. Proximate composition, mineral and some vitamin contents of tigernut (Cyperus esculentus). Clin Invest. (Lond). 2018;8(4):161-5.

15. Wong $W$, Zhou $Y$, Huang $X$, Zhang Q. Preparative isolation and purification of cyperotundone and acyperone from Cyperus rotundus Linn. With high speed counter-current chromatography. Int J Med Aromatic Plants. 2013; 3(2):163-8.

16. Nwozo SO, Nwawuba SU. Ameliorative potentials of Cyperus esculentus oil on type 2 diabetes induced by high fat diet and low dose streptozotocin in male Wistar rats. Int J Diabetes Res. 2019;2(1):33-8.

17. Adewuyi A, Otuechere CA, Oteglolade ZO, Unuabonah El. Evaluation of the safety profile and antioxidant activity of fatty hydroxamic acid from underutilized seed oil of Cyperus esculentus. J Acute Dis. 2015:4:230-5.

18. Misra HP, Fridovich I. The univalent reduction of oxygen by reduced flavins and quinines. J Biol Chem. 1972;247:188-92

19. Sinha AK. Colorimetric assay of catalase. Anal Biochem. 1972;47:389-94.

20. Rotruck JT, Pope Al, Ganther HE, Swanson AB, Hafeman DG, Hoekstra WG. Selenium: biochemical role as a component of glutathione peroxidase. Sci. 1973;179:588-90.

21. Habig WH, Pabst MJ, Jacoby WB. Glutathione-S-transferases, the first enzymatic step in mercapturic acid formation. J Biol Chem. 1974;249:7130-9.

22. Beutler E, Duron O, Kelly BM. Improved method for the determination of blood glutathione. J Lab Clin Med. 1963:61:882-8.

23. Varshney R, Kale RK. Effect of calmodulin antagonists on radiation-induced lipid peroxidation in microsomes. Int J Radiat Biol. 1990;58:733-43.

24. Gornall AC, Bardwawill CJ, David MM. Determination of serum protein by means of the biuret reaction. J Biol Chem. 1949;177:751-6.

25. Regoli F, Principato G. Glutathione, glutathione dependent and antioxidant enzymes in mussel, mytilus galloprovincialis, exposed to metals under field and laboratory conditions: implications for the use of biochemical biomarkers. Aquat Toxicol. 1995;31:143-64.

26. Otuechere CA, Abarikwu SO, Olateju VI, Animashaun AI, Kale OE. Protective effect of curcumin against the liver toxicity caused by propanil in rats. Int Sch Res Notices. 2014; doi.org/https://doi.org/10.1155/2014/853697.

27. Abarikwu SO, Adebayo OI, Otuechere CA, Iserhienrhien BA, Badejo TA. Selenium and rutin alone or in combination do not have stronger protective effects than their separate effects against cadmium-induced rena damage. Pharm Biol. 2016:54:896-904.

28. El-Demerdash FM, Yousef MI, Radwan FM. Ameliorating effect of curcumin on sodium arsenite-induced oxidative damage and lipid peroxidation in different rat organs. Food Chem Toxicol. 2009;47:249-54. 
29. Abarikwu SO, Otuechere CA, Ekor M, Monwuba K, Osobu D. Modulation of cyclophosphamide-induced testicular toxicity and oxidative stress by Rutin supplementation in male Wistar rat. Toxicol Int. 2012;19:207-14.

30. Estruel-Amades S, Massot-Cladera M, Garcia-Cerdà P, Pérez-Cano FJ, Franch A, Castell M, Camps-Bossacoma M. Protective effect of hesperidin on the oxidative stress induced by an exhausting exercise in intensively trained rats. Nutrients. 2019;11:783.

31. Yen HC, Oberley TD, Vicchitbandha S, Ho YS, St Clair DK. The protective role of manganese superoxide dismutase against adriamycin-induced acute cardiac toxicity in transgenic mice. J Clin Investig. 1996;98:1253-60.

32. Mates M. Effects of antioxidant enzymes in the molecular control of reactive oxygen species toxicology. Toxicology. 2000;153(1-3):83-104.

33. Farombi EO, Adedara IA, Oyenihi AB, Ekakite E, Kehinde S. Hepatic, testicular and spermatozoa antioxidant status in rats chronically treated with Garcinia kola seed. J Ethnopharmacol. 2013;146:536-42.

34. Adewuyi A, Otuechere CA, Adebayo OL, Anazodo C, Pereira FV. Renal toxicological evaluations of sulphonated nanocellulose from Khaya sengalensis seed in Wistar rats. Chem Biol Interact. 2018;284:56-68.

35. Celik I, Tuluce $Y$, Isik I. Evaluation of toxicity of abscisic acid and gibberellic acid in rats: 50 days drinking water study. J Enzyme Inhib Med Chem. 2007; 22:219-26.

36. Kukoba TV, Seredenko MM, Butovych IA, Moibenko OO. The effect of linoleyl hydroxamic acid on lipid peroxidation processes and on the enzymatic activity of the antioxidant system in rats under hypoxia. Fiziol Zh. 1998;5-6:43-8

\section{Publisher's Note}

Springer Nature remains neutral with regard to jurisdictional claims in published maps and institutional affiliations.

\section{Submit your manuscript to a SpringerOpen ${ }^{\circ}$ journal and benefit from:}

- Convenient online submission

- Rigorous peer review

- Open access: articles freely available online

- High visibility within the field

Retaining the copyright to your article

Submit your next manuscript at $\boldsymbol{\nabla}$ springeropen.com 